\title{
Manufacturing and Characterization Process of Polymer Concrete with Aggregate from Pumice Stone and Corn Husk Fiber as a Filler
}

\author{
Awan Maghfirah ${ }^{1^{*}}$, Lukman Hakim ${ }^{2}$ and Muhammadin Hamid $^{3}$ \\ ${ }^{1,2,3}$ Department of Physics, Faculty of Mathematics and Natural Science, Universitas Sumatera Utara \\ 20155, Indonesia
}

\begin{abstract}
Research has been carried out regarding the manufacturing process of polymer concrete made from a mixture of pumice, sand (1:1), corn husk fiber, epoxy and thinner resin. This research was conducted to determine the characterization of polymer concrete which will be tested physically and mechanically with the best composition mixture. The physical properties of polymer concrete which were analyzed namely density, porosity and water absorption; mechanical properties including impact strength, flexural strength and compressive strength, and polymer concrete microstructure analysis, namely SEM-EDX. The best results were obtained with a mixture of pumice, sand (1:1), corn husk fiber, epoxy and thinner resin. The result are as stated here, density: $1.84 \mathrm{~g} / \mathrm{cm}^{3}$ with composition (49:49:2) 30 g epoxy resin, porosity: $0.44 \%$ with composition (50:50:0) $20 \mathrm{~g}$ epoxy resin, water absorption: $1.8 \%$ with composition (50:50:0) $25 \mathrm{~g}$ of epoxy resin. Whereas mechanical properties, on impact tests: $4.956 \mathrm{KJ} / \mathrm{m}^{2}$ with composition of (47:47:6) $25 \mathrm{~g}$ epoxy resin, flexural test: $22.22 \mathrm{MPa}$ with composition of (45:45:0) $30 \mathrm{~g}$ epoxy resin, pressure test: $8.41 \mathrm{MPa}$ with composition of (49:49:2) $30 \mathrm{~g}$ epoxy resin. XRD analysis shows that each of its constituents still have quartz, pumice, quartz, pumice-shaped hexagonal crystals, while corn husk fibers are amorphous crystals. The average sound absorption coefficient for the three samples $(20 \%, 25 \%$, and $30 \%)$ are $0.178 ; 0.152$; and 0.234 at a frequency of $500 \mathrm{~Hz}-6300 \mathrm{~Hz}$, which meets the requirements of ISO 11654 and ASTM C.384.
\end{abstract}

Keyword: Polymer Concrete, pumice, Corn Skin Fiber and Epoxy Resin, sound absorption coefficient

Received 2 December 2018 | Revised [20 February 2019] | Accepted [28 February 2019]

\section{Introduction}

Along with the latest development, there are major building structure materials, namely: wood, steel and concrete. Out of the three, the most common material is concrete. Starting from pipes, electric poles, foundations, dams, bridges, sports centers, to skyscrapers. Even large cities that are filled with buildings are sometimes called concrete. During the era of globalization and

*Corresponding author at: Jl. Bioteknologi No.1 Kampus USU, Medan, Indonesia, 20155

E-mail address: awan.maghfirah@usu.ac.id 
development, Indonesia is not only starting to improve itself in the economic and political sector but also beginning to experience rapid development in the construction sector. We could observe it from the number of tall buildings with dozens of floors, both hotel buildings, apartments, schools, malls to office buildings.

Concrete material engineering has developed so far, one by engineering concrete materials through the use of lightweight aggregates such as pumice. In order to speed up the hardening time of the concrete and also to be able to tightly close the cavities in the concrete, and to withstand high humidity; it is necessary to add a polymer material (epoxy resin) to the manufacturing process of concrete. Additionally, this composite can achieve mechanical strength 4-5 times higher compared to concrete cement, at the same time it is also durable and water resistance.

Corn husk is an example of an abundant agricultural waste. Corn can grow almost anywhere in Indonesia. The utilization of corn waste in the form of husk is currently not optimal. Usually, the community uses the corn waste as a wrapper for traditional food, as livestock food, mats and handicrafts in the form of ornamental flowers. Corn waste is mostly lignocellulosic material. Corn husk is made up of $36.81 \%$ cellulose, $6.04 \%$ ash, $15.7 \%$ lignin and $27.01 \%$ hemicellulose [1].

Concrete is commonly used as a material in building construction in Indonesia because of the advantages, such as the commonly-found composition ingredient which are also easy to form. Concrete is basically formed from a mixture of fine aggregates, coarse aggregates, cement and water or without additional mixture with a certain ratio. Some businesses in developed countries are actively reducing the use of cement in order to anticipate global warming, instead they are using polymer as a cement substitute adhesive so that it produces concrete with a higher compressive strength and in a shorter time. There are also alternatives to conventional cement binders such as polymer materials that are being developed today. Judging from the performance and behavior of the materials, polymer binders have different properties compared to conventional cement binders which are often used thus far. One type of polymer binder that has been studied is epoxy resin which has a relatively faster hardening time than conventional cement. This type of polymer binder is able to provide good mechanical properties [2-4].

\section{Materials and Methods}

The samples used in this study are pumice, sand and stone taken from Stabat River in Langkat, North Sumatra, and Old Corn husk in the village of Seunebok Punti, Langsa. Pumice and sand are washed and then dried in the sun, after that they are grinded with mortar and then filtered with a 100 mesh sieve to obtain a fine pumice aggregate which is then weighed for analysis of density, porosity, water absorption, compressive strength, impact strength, flexural strength, 


\section{Result and Discussion}

\subsection{Water Absorption Measurement}

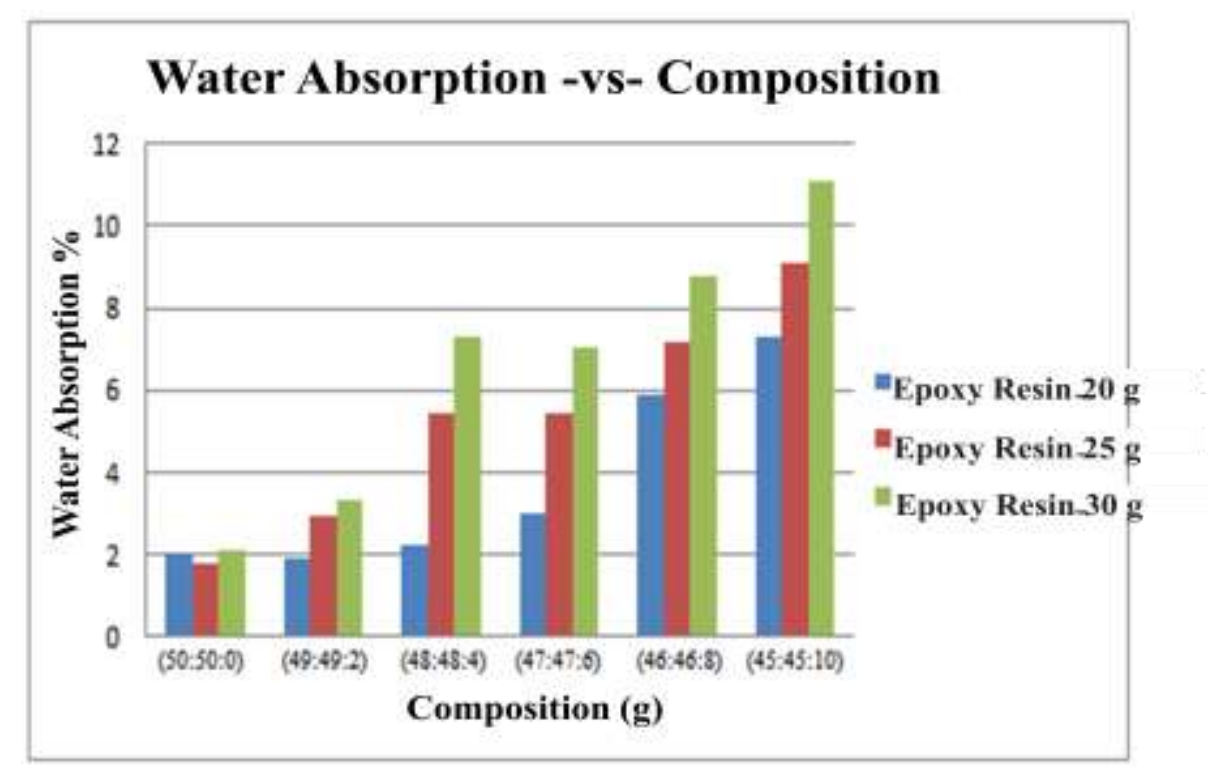

Figure 1. Correlation between Water Absorption and Composition

By adding corn husk fiber, the water absorption value tends to increase, and when the amount of epoxy resin is increased as well, it immensely affects the value of water absorption in polymer concrete. This is caused by the presence of epoxy resin as a binder. Therefore, the pores' size in the polymer concrete are decreasing. If the water absorption in the polymer concrete decreases, the polymer concrete will become more resistant and increase in quality.

From the results of the observation, it showed that the best conditions were obtained in the (50:50:0) composition and the weight of the epoxy resin was $20 \%$ of the total weight, the water absorption value was obtained at $1.9 \%$. This means that the polymer concrete obtained relatively does not absorb water and has a non-hollow surface. With the least cavity contained in the sample, there is less water absorption. For pumice cement concrete with a mixture of cement, sand and pumice with open air hardening conditions, water absorption is around $7.84 \%$. For conventional concrete generally has a water absorption value of 5.5\% [5]. This shows the absorption value of polymer concrete water which is made better than conventional concrete.

\subsection{Impact Strength Testing}

As the amount of corn husk fiber increased, the impact strength also increased at the same time. Likewise, the addition of epoxy resin to the composition greatly affects the impact strength, because epoxy resin has a good binding ability. This has been proven by several data on natural 
bending studies such as those carried out by [6-10], and also the natural binder using natural rubber [11-16], concluded that natural binders can improve mechanical properties due to the physical or chemical interactions between two or more components. The right composition for a good polymer concrete is the one with the highest impact strength, in this case the highest impact strength is in the B4 sample with the composition of (47:47:6). It could be observed that the impact strength value of 30 grams of epoxy resin is better than 25 grams of epoxy resin and 20 grams because the bond strength of 30 grams of epoxy resin is better. The influence of the proportion of constituent materials and homogeneity of the materials mixture are also the reason for the impact strength test results on the polymer concrete.

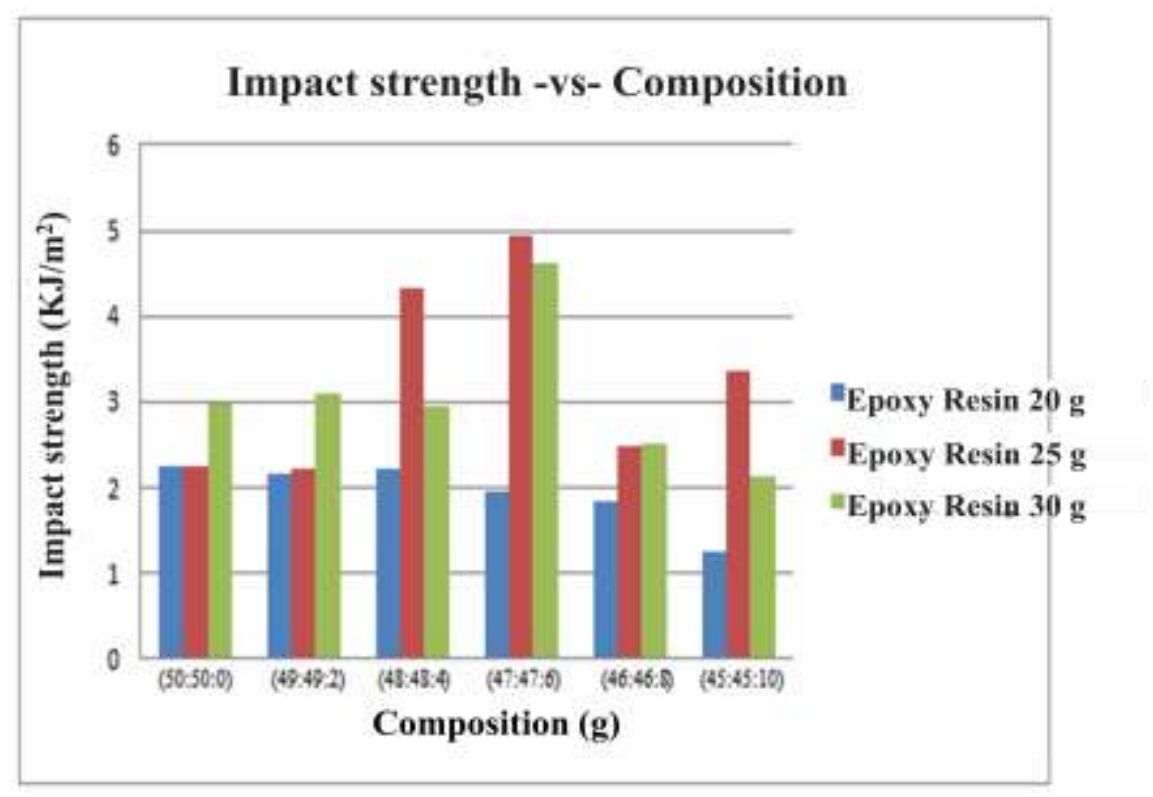

Figure 2. Chart of impact strength testing with composition

\subsection{Bend Test/Flexural Test}

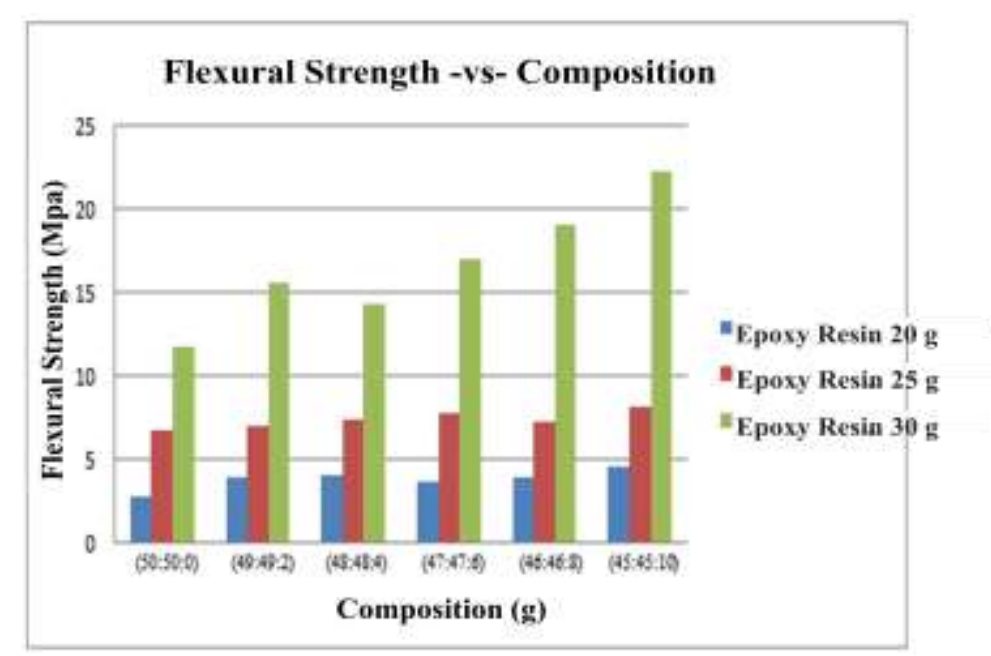

Figure 3. Chart of impact strength testing with composition

The flexural strength of polymer concrete ranges from 2.81 to $22.2 \mathrm{MPa}$. From the graph, it can be seen that as the amount of sand and pumice increase, the flexural strength increases and if the 
corn husk fiber is added, the flexural strength will decrease. Whereas, with the composition of epoxy resin, the higher the addition of epoxy resin tends to increase its flexural strength.

From Figure 3, the polymer flexural strength value of the maximum flexural strength of 22.2 $\mathrm{MPa}$ is in the composition of (50:50:0) with epoxy resin 20\% of the total weight, and the minimum flexural strength is $2.81 \mathrm{MPa}$ ie at composition of (50:50:0) with $20 \%$ epoxy resin. This shows that the reduced bonding of aggregate elements can also occur due to reduced adhesive ability so that the bond between particles is low.

Hence, there is no homogeneity on the polymer mixture. When the amount of epoxy resin increased, the flexural strength will be increased as well. It happened because epoxy resin is able to easily flow and fill the cavity - Existing cavities or covering on Micro crack in order to increase the flexural strength.

\subsection{Compression Testing}

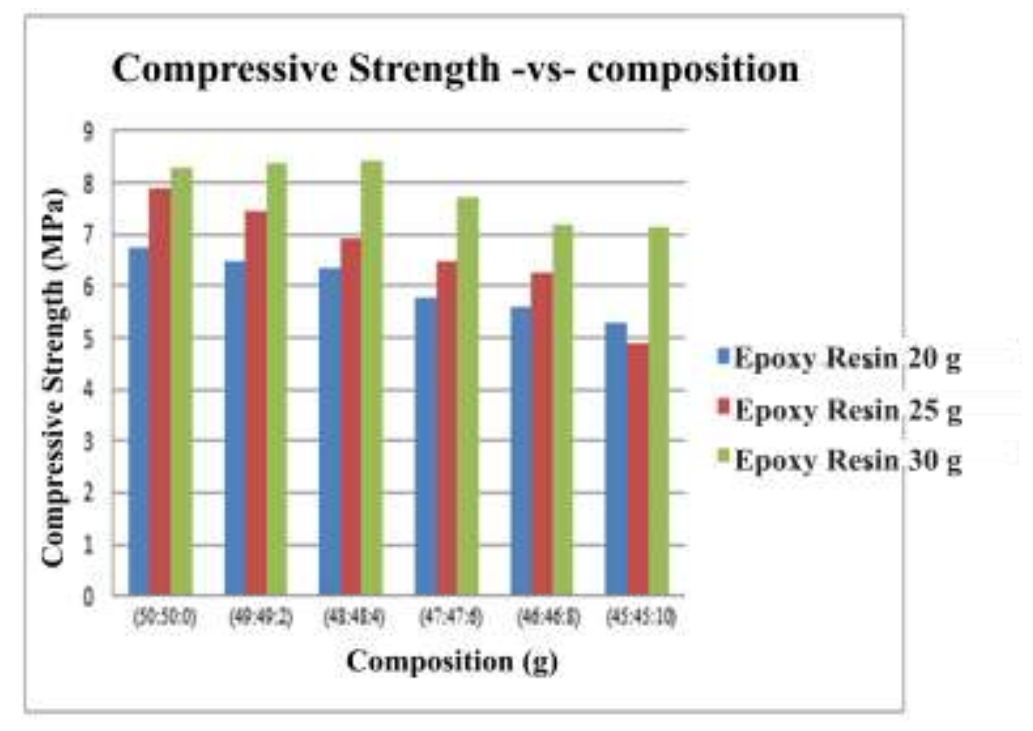

Figure 4. Correlation between compressive strength with composition

The compressive strength value of the polymer concrete ranged between 4.91 - 8.41 MPa. The graph displayed the addition of corn husk fiber has a great impact in decreasing the compressive strength due to the distribution of pores in sand, pumice and corn husk fibers. The compressive strength value will increase if the amount of epoxy resin is added due to its bond to sand, pumice and corn husk fibers and increases its strength. Furthermore, the adhesive functionality of epoxy resin can increase the compressive strength of the polymer concrete. Thus, the optimum conditions achieved in $0 \mathrm{gr}$ corn husk fiber with 30\% epoxy resin from the total weight generated compressive strength value of 8.41 MPa. While, the lowest compressive strength was achieved with 10 gr corn husk fiber with $25 \%$ epoxy resin which resulted in compressive strength values of $4.91 \mathrm{MPa}$. Previous research on normal concrete with the addition of $5 \%$ by 

weight of polyethelen type polymer material produced a compressive strength of $23.3 \mathrm{MPa}[17$, $18]$.

\subsection{SEM-EDX Testing}

In the Figure 5, SEM-EDX testing was carried out on polymer concrete samples with the composition of (50:50:0) and $20 \mathrm{~g}$ epoxy resin. From the results of the SEM test at $1000 \mathrm{X}$ magnification, it can be seen in black which possesses quite a lot of cavities in the polymer concrete; due to a mixture of pumice, sand and epoxy resin which is uneven. However, the bright white color shows that the epoxy resin binds well to the mixture so that it covers the pores even though the surface is uneven.

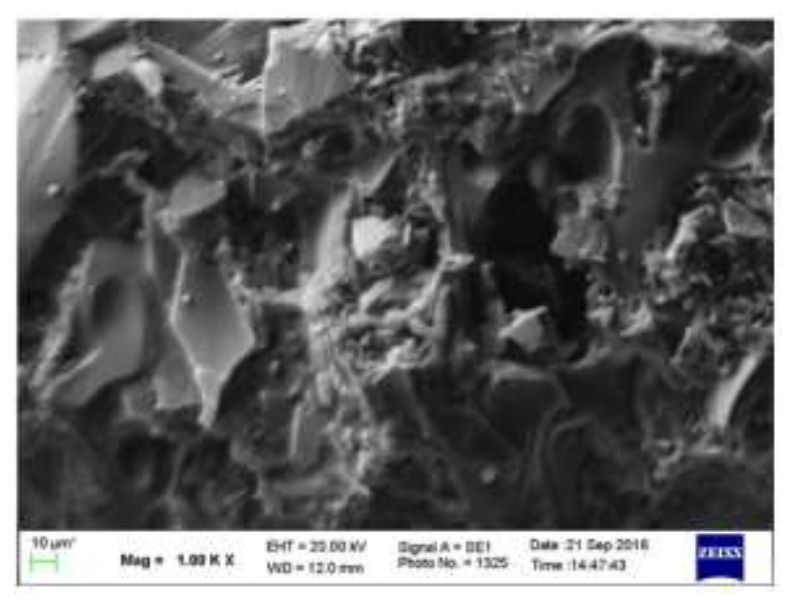

Figure 5. SEM-EDX testing with 1000X magnification (50: 50: 0)

The SEM test in the Figure 6 was carried out on the polymer concrete sample with the composition of (47:47:6) and with the addition of $25 \mathrm{~g}$ resin. It can be seen that this sample is better than the composition of (50:50:0) with the addition of $20 \mathrm{~g}$ epoxy resin. The picture displayed that the bright white color is an epoxy resin which covers a mixture of pumice, sand and corn husk fiber so that it look more evenly distributed, and the size of the polymer concrete grain is very compact.

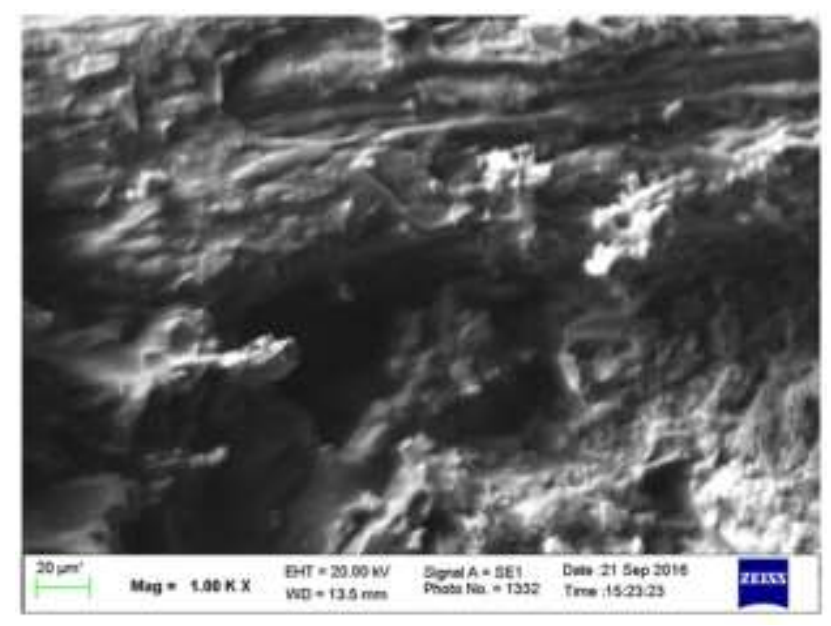

Figure 6. SEM-EDX testing with 1000X magnification (47:47:6) 


\subsection{SEM-EDX testing with 1000X magnification (47:47:6)}

The X-ray diffraction pattern shows the highest peaks. The diffraction pattern of polymer concrete with $20 \%$ epoxy resin and from the peak-(intensity) data list of pdf (5-0.490). Visible polymer concrete consists of peaks belonging to sand (quartz) at $\mathrm{d}=4.22 \mathrm{~A}, 3.32 \AA \mathrm{A}, 2.40 \AA \AA$,

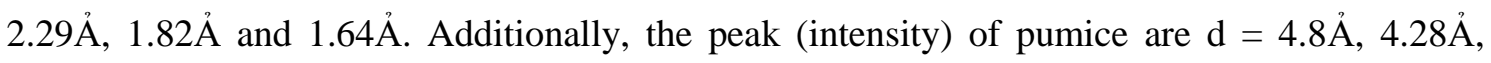

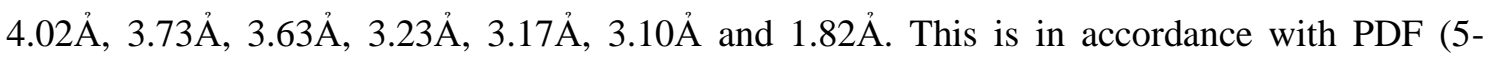
$0.490)$.

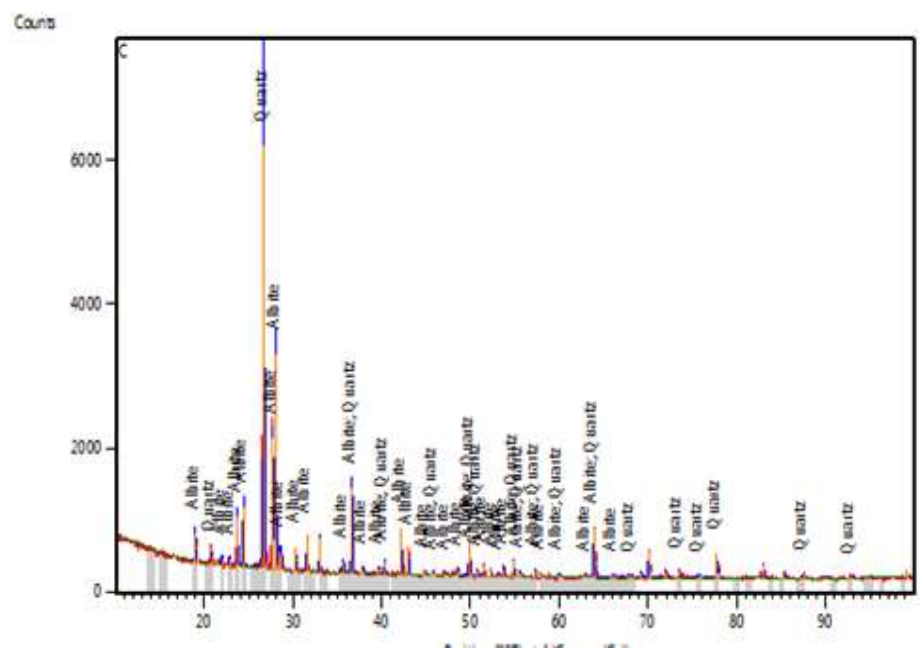

Figure 7. X-ray diffraction pattern of polymer concrete $30 \%$ (47:47:6)

\subsection{Sound Absorption Analysis (Sound Absorption Coefficient)}

Table 1. Data of sound absorption coefficient value $\alpha$ with frequency

\begin{tabular}{ccccccc}
\hline \multicolumn{7}{c}{ Sound Absorption Ref to ASTM E-1050-98 } \\
\hline Specimen Code & \multicolumn{7}{c}{ Absorption Coefficient } \\
\cline { 2 - 7 } & $500 \mathrm{~Hz}$ & $800 \mathrm{~Hz}$ & $1 \mathrm{kHz}$ & $1,6 \mathrm{kHz}$ & $4 \mathrm{kHz}$ & $6,3 \mathrm{kHz}$ \\
\hline $\mathbf{2 0} \%$ & 0,0315 & 0,0436 & 0,0574 & 0,111 & 0,510 & 0,32 \\
$\mathbf{2 5} \%$ & 0,0367 & 0,0547 & 0,0673 & 0,127 & 0,367 & 0,262 \\
$\mathbf{3 0} \%$ & 0,0607 & 0,139 & 0,272 & 0,696 & 0,114 & 0,124 \\
\hline
\end{tabular}

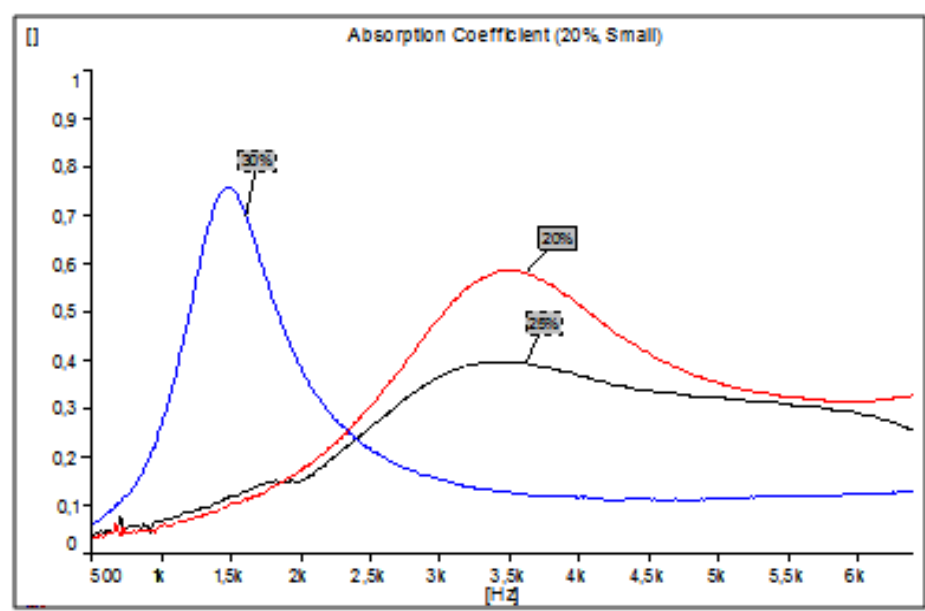

Figure 8. Relationship between $\alpha$ Sound Absorption Coefficient and Frequency 
Of the three samples with a $20 \%, 25 \%, 30 \%$ epoxy resin mixture, it showed that the formation of particles is not homogeneous at greater frequencies resulting in an absorption coefficient fluctuating due to the uneven size of the granules and vacancies in the sample.

Out of the three best samples in the $30 \%$ sample with a sound absorption coefficient of 0.234 , it meets the requirements of ISO 11654 and ASTM C.384. The high attenuation power caused by $30 \%$ of epoxy resin shows that epoxy resin is able to improve certain properties of polymer concrete, an increase in optimal sound attenuation power (30\% sample) indicates that epoxy resin has advantages over using natural epoxy resins. Because in natural epoxy resins there are still other compounds contained in lignin and react in a polymeric network that forms natural epoxy resins. [19, 20] In natural epoxy resins there are still many phenol compounds and derivative compounds that can improve the properties of the damping power of polymer concrete.

Of the three samples with a $20 \%, 25 \%, 30 \%$ epoxy resin mixture, it showed that the formation of particles is not homogeneous at greater frequencies resulting in an absorption coefficient fluctuating due to the uneven size of the granules and vacancies in the sample.

\section{Conclusion}

From the results of the research that has been done, it can be concluded:

1. As the amount of corn husk fiber increases, the physical properties decrease, thus making polymer concrete lighter and increasing its water absorption value. Whereas, the mechanical properties of corn husk are increasing, the greater the value of impact strength and flexural strength. On the other hand, the more the corn husk fiber increases, the smaller the compressive strength of the polymer concrete.

2. Characterization of polymer concrete with the best composition mixture in the form of physical properties, with a density: $1.84 \mathrm{~g} / \mathrm{cm}^{3}$ with composition of (49:49:2) $30 \mathrm{~g}$ epoxy resin, porosity: $0.44 \%$ with composition of (50:50:0) $20 \mathrm{~g}$ epoxy resin, water absorption: $1.8 \%$ with a composition of (50:50:0) of $25 \mathrm{~g}$ of epoxy resin. While the mechanical properties, at impact test: $4.956 \mathrm{KJ} / \mathrm{m}^{2}$ with composition of (47:47:6) $25 \mathrm{~g}$ epoxy resin, flexural test: $22.22 \mathrm{MPa}$ with composition of (45:45:0) $30 \mathrm{~g}$ epoxy resin, press test: 8.41 MPa with a composition of (49:49:2) $30 \mathrm{~g}$ epoxy resin. SEM-EDX microstructure is also influenced by the mixture composition of pumice, sand (1:1), corn husk fiber and epoxy resin. The sample surface and porosity will be well distributed if the epoxy resin binds well so that there is not much cavity in the polymer concrete. Characteristics of sound attenuation properties show the role of natural polyurethane as a binder as much as $30 \%$ with the composition (47:47:6) is the best sample with a sound absorption coefficient of 0.234 this value in accordance with the requirements set by ISSO 11564 and ASTM C.384. 


\section{References}

[1] Z. Rangkuti, "Pembuatan dan Karakterisasi Papan Partikel dari Campuran Resin Polyester dari Serat Kulit Jagung," Magister Fisika, Fakultas Matematika Universitas Sumatera Utara, Medan, 2010.

[2] H. Efendy, "Studi Strukturmikro Pengikatan Resin Epoksi Pada Beton," Jurnal Penelitian Enjiniring, vol. 12, no. 2, pp. 135-140, 2009.

[3] J. Arif, H. R. Husni and S. Sebayang, "Pengaruh Resin Epoksi Terhadap Mortar Polimer Ditinjau dari Kuat Tekan, Kuat Tarik Belah, Daya Serap Air dan Scanning Electron Microscope," Jurnal Rekayasa Sipil dan Desain, vol. 3, no. 3, pp. 361-370, 2016.

[4] L. Lasino, N. R. Setiati and D. Cahyadi, "Pengembangan Mikro Lumpur Sidoarjo Sebagai Bahan Subtitusi Semen Dalam Pembuatan Beton," Jurnal Rekayasa Sipil (JRS-Unand), vol. 14, no. 1, pp. 49-62, 2018.

[5] A. Balaga and J. J. Beaudoin, Polymer Modified Concrete, Canada: Canadian Building Digest 241, 1985.

[6] V. Gonzales, "A Study into the Processing of Bitumen Modified with Tire Crumb and Polymer," Journal Fuel Processing Tegnology, vol. 95, pp. 137-143, 2012.

[7] A. Ait-Kadi, H. Brahimi and M. Bousmina, "Polymer blends for enhanced asphalt binders," Polymer Engineering and Science, vol. 36, pp. 1724-1733, 1996.

[8] J. H. Collins, M. G. Bouldin, R. Gelles and A. Berker, "Improved performance of paving asphalt by polymer modification," Association of Asphalt Paving Technologists, vol. 60, pp. 43-79, 1991.

[9] J. K. Newman, "Studies on the influence of cure system on the shrinkability of polyolefinbromobutyl blends," Journal of Elastomers and Plastics, vol. 30, pp. 245-263, 1998.

[10] A. A. Zaman, A. L. Fricke and C. L. Beatty, "Rheological properties of rubber-modified asphalt," Journal of Transportation Engineering, vol. 121, pp. 461-467, 1995.

[11] P. Cong, J. Wang, K. Li and S. Chen, "Physical and Rheological Properties of Asphalt Binders Containing Various Antiaging Agents," Journal Fuel, vol. 97, pp. 678-684, 2012.

[12] X. H. Lu and U. Isacsson, "Effect of ageing on bitumen chemistry and rheology," Constr Build Mater, vol. 16, pp. 15-22, 2002.

[13] F. C. Ouyang, S. F. Wang, Y. Zhang and Y. X. Zhang, "Improving the aging resistance of styrene-butadiene-styrene tri-block copolymer modified asphalt by addition of antioxidants," Polym Degrad Stabil, vol. 91, pp. 795-804, 2006.

[14] S. Lee, J. Hu, H. Kim, S. N. Amirkhanian and K. D. Jeong, "Aging analysis of rubberized asphalt binders and mixes using gel permeation chromatography," Constr Build Mater, vol. 25, pp. 1485-1490, 2011.

[15] B. Colbert and Z. You, "The properties of asphalt binder blended with variable quantities of recycled asphalt using short term and long term aging simulations," Constr Build Mater, vol. 26, p. 552-557, 2012.

[16] S. Lee, S. N. Amirkhanian and K. W. Kim, "Laboratory evaluation of the effects of shortterm oven aging on asphalt binders in asphalt mixtures using HP-GPC," Constr Build Mater, vol. 23, pp. 3087-3093, 2009.

[17] E. Yuli, "Pengaruh Penambahan Polimer Jenis Polyethilene Terhadap Tekanan Beton," Politeknik Negeri Sriwijaya, Palembang, 2008.

[18] P. Gunawan, W. Wibowo and N. Suryawan, "Pengaruh Penambahan Serat Polypropylene pada Betonringan dengan Teknologi Foam Terhadap Kuat Tekan, Kuat Tarik Belah dan Modulus Elastisitas," Matriks Teknik Sipil, vol. 2, no. 2, pp. 206-213, 2014.

[19] Bilmayer, Text book of polymer third edition, New York: Jhon Willey and Son, 1984.

[20] A. Rudin, Elements of Polymer Science \& Engineering: An Introductory Text and Reference for Engineers and Chemists, Elsevier, 1998. 